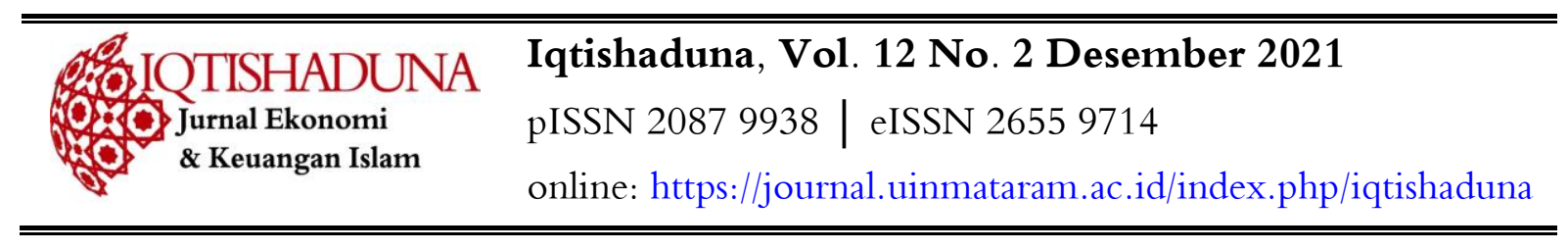

\title{
CAPITALIZATION RATE ON RESIDENTIAL SECTOR IN MATARAM
}

\author{
Safwira Guna Putra \\ Universitas Islam Negeri Mataram \\ gunaputra@uinmataram.ac.id
}

\begin{abstract}
The capitalization rate is an important factor and must be presented in order to valuing a property applying income approach and direct capitalization method. This paper attempt to measure the capitalization rate on residential sector in district of Mataram through the overall capitalization rate theory developed by the International Association of Assessment Officers. Measurements of central tendency and dispersion were conducted to find out early indications related to the characteristics and tendencies of the capitalization rate. In addition, regressivity and progressivity test was conducted through simple regression analysis and Spearman rank test correlation to determine the lease pattern. Utilizing purposive sampling as many as 70 samples were divided proportionally according to number of sub-district. This research showed that average capitalization rate in district is $4.39 \%$, while average capitalization rate for each subdistrict varied widely from $3.7 \%$ to $5.31 \%$. Individually, the highest capitalization rate is $6.15 \%$ and the lowest is $3.33 \%$. Higher capitalization rate indicated higher percentage return than lower capitalization rate. Regression and correlation analysis showed that capitalization rate tends to regressive against market price or there is a regressive relationship between capitalization rate and market price. The interesting result of this paper is a property with higher market price has lower percentage return than a property with lower market price, and vice versa.
\end{abstract}

Keywords: capitalization rate, residential sector, regressivity and progressivity

\section{PENDAHULUAN}

Kebutuhan akan tempat tinggal merupakan salah satu kebutuhan pokok manusia selain sandang dan pangan. Bagi masyarakat yang berpenghasilan rendah kecil dan menengah, pemenuhan akan tempat tinggal menjadi problem tersendiri karena tingginya harga rumah dan keterbatasan dana untuk membeli/memiliki tempat tinggal. Semakin pesatnya perkembangan perekonomian dan semakin banyaknya jumlah penduduk dari tahun ke tahun berdampak pada semakin tingginya kebutuhan akan rumah tinggal, sehingga menciptakan peluang bisnis yaitu pemilikan rumah tidak hanya ditujukan untuk rumah tinggal melainkan menjadi suatu alternatif investasi yang cukup menarik. Dewasa ini pilihan - pilihan investasi pada sektor perumahan memiliki banyak variasi dari yang modern seperti kondominium dan apartemen, sampai jenis yang sederhana seperti rumah susun sederhana dan rumah biasa. Pilihan obyek investasi ini juga memiliki karakteristik yang berbeda dilihat dari risiko, biaya dan potensi pendapatannya. 
Kondisi pasar properti (sektor perumahan) disaat pandemi covid-19 seperti saat ini masih mengalami stagnasi. Investor (pengembang perumahan ataupun pembeli properti dengan tujuan investasi) masih menunggu waktu yang tepat untuk membelanjakan uangnya. Psikologi masyarakat saat ini lebih memilih untuk memegang uang cash (aset likuid) daripada aset non likuid. Rendahnya daya beli masyarakat jika terjadi secara terus menerus akan berdampak pada turunnya harga properti. Secara makro, kondisi pasar properti di suatu daerah dapat dilihat dari sisi konsumsi dan sisi penawaran. Bank Indonesia melaporkan bahwa perekonomian NTB pada tahun 2020 mengalami kontraksi 0,64\% (yoy), lebih rendah dibandingkan tahun 2019 yang tumbuh 3,90\% (yoy), sumber penurunan dari sisi permintaan (demand side) adalah penurunan kinerja konsumsi rumah tangga, konsumsi pemerintah dan pembentukan modal tetap domestik bruto (PMTB) sejalan dengan dampak pandemi Covid-19, sementara penurunan dari sisi penawaran (supply side) bersumber dari penurunan kinerja seluruh lapangan usaha utama kecuali lapangan usaha pertambangan yang tumbuh signifikan (Laporan Perekonomian Provinsi NTB, Kantor Perwakilan Bank Indonesia Provinsi NTB, Februari 2021).

Investasi pada sektor properti merupakan investasi yang membutuhkan dana yang relatif besar dan bersifat jangka panjang, karena itu investor merasa perlu untuk melakukan analisis secara mendalam terkait dengan potensi risiko dan potensi pendapatan yang ada. Untuk mengetahui kemampuan suatu investasi menghasilkan keuntungan, perlu mengetahui potensi nilai dari properti tersebut yang tercermin dari pola aliran pendapatannya. Lusht (1997: 234-235) berpendapat bahwa nilai properti adalah fungsi pendapatan yang diharapkan dari properti tersebut. Untuk mengkonversi aliran pendapatan menjadi sebuah nilai properti maka diperlukan suatu tingkat kapitalisasi tertentu. Tingkat kapitalisasi adalah sebuah faktor yang penting untuk mengkonversi estimasi pendapatan bersih tahunan menjadi estimasi nilai pasar atau dapat juga didefinisikan sebagai angka perbandingan antara pendapatan operasional bersih terhadap nilai pasarnya (Appraisal Institute, 2001: 474).

Dalam penentuan nilai properti melalui metode kapitalisasi pendapatan, keakuratan dalam penentuan tingkat kapitalisasi ini mempunyai pengaruh yang penting (significant), karena perbedaan satu angka (point) saja dapat menghasilkan perbedaan nilai yang cukup besar. Acceta (1998: 371374) mengidentifikasikan tiga metode yang dapat digunakan untuk menentukan tingkat kapitalisasi yang wajar, yaitu melalui analisis pasar (market analysis), analisis komponen pembentuknya, dan melalui survei investor (investor surveys). Berkenaan dengan metode penentuan tingkat kapitalisasi ini, dikatakan bahwa teknik penurunan tingkat kapitalisasi melalui perbandingan harga jual adalah lebih dipilih bila terdapat data jual beli yang cukup dari properti - properti yang serupa (AIREA,1987: 514). 
Penentuan nilai yang baik tergantung pada kesesuaian metode yang digunakan untuk mengestimasi nilai. Di Indonesia, terdapat tiga pendekatan penilaian yang lazim digunakan, yaitu pendekatan perbandingan data pasar (market data comparison approach), pendekatan biaya (cost approach) dan pendekatan kapitalisasi pendapatan (income capitalized approach). Dari ketiga pendekatan penilaian tersebut, metode kapitalisasi pendapatan adalah metode penentuan nilai properti berdasarkan pada kapitalisasi pendapatan bersih tahunan (annual net income) dengan suatu tingkat kapitalisasi (capitalization rate) tertentu. Metode penilaian ini didasarkan pada prinsip bahwa besarnya nilai properti tergantung pada besarnya aliran pendapatan yang dapat dihasilkan oleh properti tersebut. Untuk mengkonversi setiap aliran pendapatan tersebut menjadi indikasi nilai, maka dilakukan suatu proses pengkapitalisasian pendapatan (Appraisal Institute, 2001: 474-475).

Dalam praktik penilaian di Indonesia saat ini, baik yang dilakukan oleh para penilai independent atau oleh penilai pemerintah khususnya di bidang pajak properti (pajak bumi dan bangunan), penggunaan pendekatan pendapatan melalui prosedur pengkapitalisasian pendapatan bersih ini jarang sekali atau bahkan belum pernah dilakukan, meskipun metode kapitalisasi ini adalah metode yang sangat efisien apabila diterapkan dan Undang-undang No.12 tahun 1994 pasal 1 (3) memberi peluang untuk menerapkannya. Beberapa hal yang menjadi kendala adalah sulitnya untuk memperoleh informasi harga properti yang transparan dan terbatasnya tenaga yang mampu untuk melakukan penelitian. Mengingat hal di atas, maka dipandang perlu (penting dan menarik) untuk dilakukan analisis tentang tingkat kapitalisasi, khususnya di sektor perumahan yang merupakan jenis properti yang paling dominan dan paling sering ditransaksikan.

\section{STUDI LITERATUR}

Penelitian mengenai tingkat kapitalisasi merupakan penelitian yang sangat bermanfaat bagi seorang penilai dan investor, dimana hal ini adalah upaya untuk mempermudah dalam penentuan nilai pasar (market value) properti, selama ini metode yang paling sering dipakai hanyalah metode biaya (cost method). Selain itu, dalam melakukan analisis dan pengambilan keputusan investasi, investor sangat memperhatikan dua hal penting yaitu perolehan (return) dan risiko yang terdapat pada investasi tersebut di mana kedua faktor tersebut tercermin dalam tingkat kapitalisasinya.

Sivitanidou dan Sivitanides (1997: 1-11) menganalisis perbedaan tingkat kapitalisasi dari berbagai tipe properti yaitu, perkantoran, pergudangan, retail, dan apartemen. Hasil penelitian menyimpulkan bahwa tingkat kapitalisasi dari berbagai jenis penggunaan properti tersebut berbeda antara satu dengan yang lainnya. Simons, dkk (2011: 1-10) meneliti tentang variasi tingkat kapitalisasi perumahan sedunia dengan menggunakan data lebih dari 100 negara. Dalam penelitian ini, untuk mendapatkan model estimasi tingkat kapitalisasi yang akurat secara internasional 
memanfaatkan data dari sumber yang bergam, seperti World Bank, Global Property Guide, UN Habitat dan data-data pendukung dari sumber yang dipercaya. Adapun model dan variabel yang dianalisis adalah sebagai berikut.

\section{Cap Rate $=\beta o+\beta 1$ Housing $+\beta 2$ Market $+\beta 3$ Periode $+\beta 4$ Political $+\beta 5$ Taxlaw $+\beta 6$ Demographics $+\beta 7$ Continent $+€$}

Dari hasil penelitian diperoleh hasil yaitu, pertama, tingkat kapitalisasi yang lebih rendah berhubungan dengan pengumpulan penerimaan pajak, ketersediaan kredit dan variabel dummy untuk negara yang sedang berkembang. Kedua, tingkat kapitalisasi perumahan meningkat ketika biaya transaksi tinggi. Sebelum melakukan estimasi tingkat kapitalisasi, perlu untuk diidentifikasi faktor-faktor yang berpengaruh terhadap besarnya tingkat kapitalisasi. Penelitian Mooney, Vergin dan Mortrude (1998: 366-370) menyebutkan bahwa faktor-faktor yang mempengaruhi tingkat kapitalisasi adalah tempo sewa (lease term), pilihan- pilihan dalam sewa, tahap penyewaan dan koefisien beta dari saham penyewa. Hasil penelitian menunjukkan bahwa 90 persen variabilitas nilai tingkat kapitalisasi keseluruhan (overall capitalization rate) dijelaskan oleh 3 variabel, yaitu tempo dan pilihan sewa, koefisien beta dari saham penyewa dan tahap pembayaran sewa yang terdapat dalam penyewaan.

Sivitanides, dkk (2001: 1-27) meneliti tentang faktor penentu tingkat kapitalisasi, menggunakan data pendapatan bersih dan harga pasar properti untuk penentuan tingkat kapitalisasi. Hasil penelitian menyimpulkan bahwa tingkat kapitalisasi sangat berbeda diberbagai pasar dikarenakan karakteristik pasar yang berbeda mempengaruhi persepsi investor terhadap risiko dan atau ekspektasi pertumbuhan pendapatan. Argensio dan Laurin (2007: 1-41) melakukan analisis faktor penentu tingkat kapitalisasi sektor perkantoran dengan menggunakan sampel dari 52 negara-negara yang sedang berkembang, asumsi dalam penelitian ini didasarkan pada capital asset pricing model (CAPM), yaitu tingkat kapitalisasi seharusnya proporsional terhadap persepsi risiko suatu negara, di mana risiko negara diukur dengan risiko premium pada tingkat pengembalian obligasi negara yang jatuh tempo 10 tahun. Hasil penelitian menunjukkan bahwa tingkat pengembalian obligasi negara merupakan faktor yang paling menentukan besarnya tingkat kapitalisasi. Dengan menggunakan Hausman-Taylor random effect, diestimasi bahwa peningkatan 1 persen pada tingkat pegembalian obligasi negara akan meningkatkan tingkat kapitalisasi sekitar 0,19 persen dan mereka menyimpulkan bahwa faktor fundamental makro ekonomi sangat berpengaruh pada besar kecilnya risiko premium obligasi negara. 
An dan Deng (2009: 1-24) meneliti hubungan tingkat kapitalisasi dengan ekspektasi dan pertumbuhan nilai sewa dengan menggunakan model dinamik untuk mengestimasi hubungan antar variabel yang dianalisis. Dalam model yang dikembangkan, tingkat kapitalisasi merupakan rata-rata tertimbang dari semua pertumbuhan masa yang akan datang yang telah disesuaikan dengan tingkat diskon tertentu. Hasil penelitian menunjukkan bahwa tingkat kapitalisasi mempunyai hubungan yang signifikan dengan ekpektasi penerimaan masa depan (future expected return) dan ekspektasi pertumbuhan sewa (expected rental growth). Ekspektasi penerimaan berhubungan secara positif dengan tingkat kapitalisasi, sedangkan pertumbuhan sewa berhubungan secara negatif dengan tingkat kapitalisasi, hal ini sesuai dengan teori umum yang mengatakan bahwa tingkat kapitalisasi yang rendah menunjukkan harapan akan nilai sewa yang lebih tinggi.

Secara garis besar, penelitian di atas masih bersifat umum, berlaku untuk berbagai jenis properti pada suatu kawasan tertentu. Penelitian tersebut tidak menjelaskan secara khusus mengenai tingkat kapitalisasi di sektor perumahan dan juga tidak menjelaskan pola sewa sektor perumahan. Oleh karena itu, penelitian ini berusaha untuk melakukan pengukuran tingkat kapitalisasi dan sekaligus menganalisis pola sewa sektor perumahan di Mataram.

\section{METODE}

Untuk menjawab tujuan penelitian ini, analisis dibagi menjadi dua yaitu; Pertama, dilakukan penghitungan tingkat kapitalisasi untuk semua sampel dilokasi penelitian. Kedua, untuk mengetahui pola sewa properti dilakukan pengukuran tendensi sentral dan pengukuran dispersi tingkat kapitalisasi di lokasi penelitian, selain itu juga dilakukan uji regresivitas/progresivitas. Secara lebih rinci analisis yang dilakukan adalah seperti diuraikan berikut ini.

\section{Pengukuran Tingkat Kapitalisasi}

Penentuan besarnya tingkat kapitalisasi sektor perumahan di Kecamatan Mataram didasarkan pada pengertian tingkat kapitalisasi keseluruhan (overall capitalization rate) sebagaimana didefinisikan oleh IAAO (1997: 21) yaitu tingkat kapitalisasi adalah perbandingan antara pendapatan operasional dan nilai pasar atau harga jualnya yang secara matematis dirumuskan sebagai berikut.

$$
\text { Ro }=\frac{\mathrm{M}}{\mathrm{V}}
$$

dalam hal ini.

Ro : tingkat kapitalisasi keseluruhan (overall capitalization rate). 
I : pendapatan dari sewa rumah selama satu tahun (income).

MV : nilai pasar atau harga jual properti (market value).

\section{Pengukuran Tendensi Sentral dan Dispersi.}

Pengkuran ini bertujuan untuk mengetahui indikasi awal terkait dengan karakteristik dan kecenderungan tingkat kapitalisasi sektor perumahan di daerah penelitian.Indikasi awal ini merupakan informasi penting, antara lain untuk mengetahui kecenderungan tingkat kapitalisasi apakah cenderung lebih tinggi (over capitalized) atau sebaliknya. Pengukuran tendensi sentral meliputi pengukuran nilai tengah (median), rata-rata hitung (arithmetic mean), nilai maksimal dan nilai minimal, untuk pengukuran dispersi dilakukan penghitungan standar deviasi dan varians (variance). Pengujian Regresivitas/Progresivitas. Pengujian regresivitas dan progresivitas tingkat kapitalisasi dilakukan untuk mengetahui apakah properti perumahan mempunyai nilai pasar lebih rendah disewakan pada persentase yang lebih tinggi dari nilai pasarnya, atau sebaliknya. Pengujian ini dilakukan melalui analisis korelasi Spearman rank test dan analisis regresi.

Model yang digunakan dalam dalam penelitian ini adalah model regresi yang dikembangkan oleh Anderson, Sweeney dan Willims (1996: 508) dan Gujarati (2003: 180).

$$
Y=\beta_{0}+\beta_{1} X+e
$$

dalam hal ini.

$\mathrm{Y} \quad$ : tingkat kapitalisasi perumahan $\left(\mathrm{R}_{\circ}\right)$.

$\mathrm{X} \quad$ : nilai atau harga jual pasar (MV).

$\beta_{0} \quad$ : konstanta.

$\beta_{1} \quad$ : koefisien regresi.

e : error

Hipotesis dalam analisis ini sebagai berikut.

Ho $: \beta_{1}=0$ artinya secara parsial tidak terdapat pengaruh yang signifikan dari variabel $\mathrm{X}$ terhadap variabel $Y$.

$\mathrm{Ha}: \beta_{1} \neq 0 \quad$ artinya ada sumbangan pengaruh yang signifikan dari variabel $\mathrm{X}$ secara parsial terhadap variabel $\mathrm{Y}$

\section{Data Penelitian}

Data harga sewa dan harga jual properti perumahan yang diambil merupakan data kerat lintang (cross section) di wilayah Kota Mataram (dipilih satu kecamatan saja) yang terjadi pada 
kurun waktu 2020 sampai 2021. Data transaksi jual beli dan sewa diperoleh dari sumber primer yang diperoleh dari wawancara langsung dan wawancara melalui telepon dan juga diperoleh dari sumber sekunder seperti dari REI Mataram, agen pemasaran properti di Mataram, developer baik secara online dan offline.

Penyesuaian waktu transaksi jual beli properti perumahan mengacu pada Keputusan Direktur Jenderal Pajak No. KEP.533/PJ.6/2000, dengan klasifikasi besarnya penyesuaian merujuk pada Surat Edaran Direktur Jenderal Pajak No. SE- 55/PJ.6/1999 tentang Petunjuk Teknis Analisis Penentuan Nilai Indikasi Rata-rata (NIR). Berikut ini adalah tabel yang menunjukkan persentase besarnya penyesuaian atas waktu transaksi. Dalam penelitian ini semua data transaksi jual beli ditetapkan pada tanggal penilaian tertentu.

Tabel 1. Penyesuaian Waktu Transaksi

\begin{tabular}{rcc}
\hline No. & Waktu Transaksi & Penyesuaian \\
\hline $\mathbf{1}$ & $1-3$ Bulan & $\mathbf{2 \%}$ \\
$\mathbf{2}$ & $3-6$ Bulan & $\mathbf{3 \%}$ \\
$\mathbf{3}$ & $6-9$ Bulan & $\mathbf{4 \%}$ \\
$\mathbf{4}$ & $9-12$ Bulan & $\mathbf{5 \%}$ \\
$\mathbf{5}$ & $>1-2$ Tahun & $\mathbf{1 2 \%}$ \\
$\mathbf{6}$ & $>2-3$ Tahun & $\mathbf{2 0 \%}$ \\
$\mathbf{7}$ & $>3-6$ Tahun & $\mathbf{2 8 \%}$ \\
\hline $\mathbf{8}$ & $>\mathbf{6}$ Tahun & $\mathbf{5 7 \%}$ \\
\hline
\end{tabular}

Sumber: Surat Edaran DJP, 1999.

Pengumpulan data lapangan dilakukan dengan teknik pengambilan sampel bertujuan (purposive sampling) dengan jumlah sampel 70 unit rumah. Alasan pertama penggunaan teknik ini supaya sampel yang dipilih dapat mewakili populasi sehingga diharapkan dapat memberikan hasil yang dapat diterima. Kedua, probabilitas elemen populasi yang dipilih tidak dapat diketahui dan sulit untuk mendapatkan data populasi penyewa rumah di seluruh lokasi penelitian.

Mengingat Kota Mataram cukup luas dan memiliki karakteristik yang berbeda pada setiap kecamatannya, maka untuk memudahkan dalam penelitian ini difokuskan pada satu kecamatan dan dibagi menurut jumlah kelurahannya. Adapun jumlah kelurahan di Kecamatan Mataram yaitu sembilan kelurahan, meliputi Kelurahan Pagutan, Kelurahan Pagutan Barat, Kelurahan Pagutan Timur, Kelurahan Punia, Kelurahan Pagesangan, Kelurahan Pagesangan Barat, Kelurahan Pagesangan Timur, Kelurahan Mataram Timur dan Kelurahan Pejanggik. 


\section{HASIL DAN PEMBAHASAN}

\section{Deskripsi Data}

Bagian ini membahas tentang deskripsi data nilai properti (market value) dan tingkat kapitalisasi (Ro) di lokasi penelitian. Gambar 1 di bawah ini menunjukkan variasi harga pasar properti perumahan yang berhasil dikumpulkan peneliti.

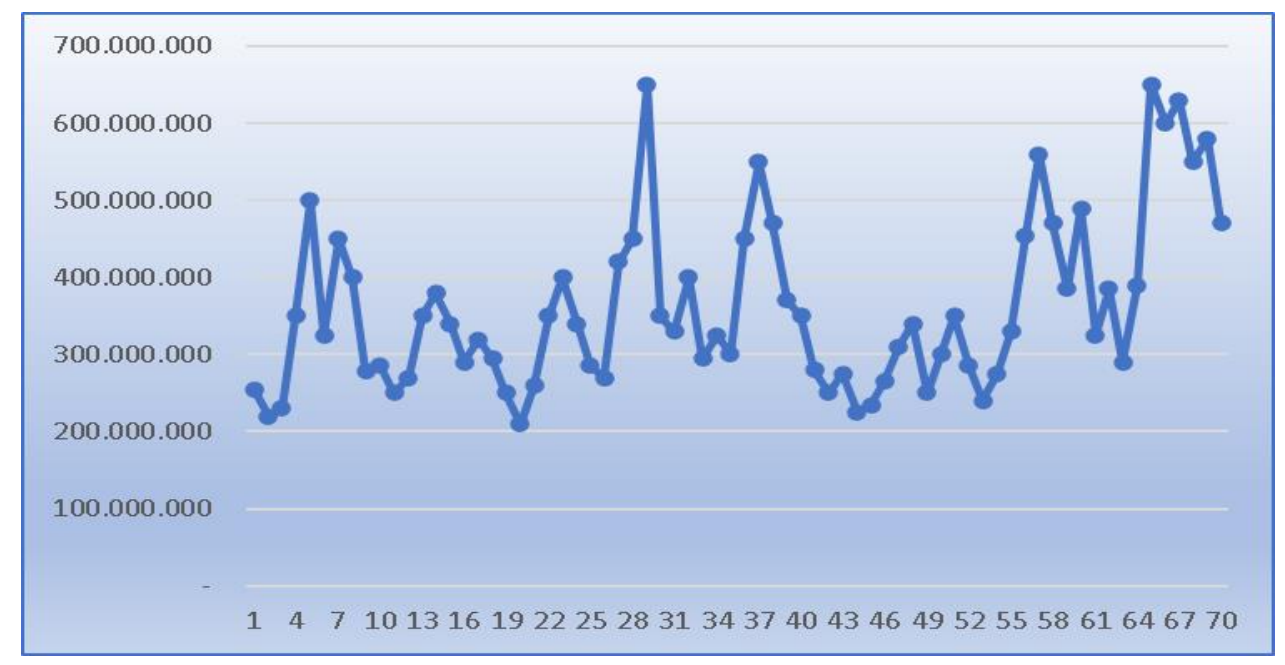

Gambar 1. Market Value Sektor Perumahan di Lokasi Penelitian

Setelah dilakukan proses pengumpulan dan validasi data, jumlah data yang memenuhi syarat dan diambil sebagai sampel sebanyak 70. Gambar 1 di atas menujukkan bahwa nilai pasar properti memiliki nilai yang beragam dimulai dari Rp210 juta s.d Rp650 juta. Data tersebut tersebar di 9 kelurahan yaitu: Pagutan Barat, Pagutan, Pagutan Timur, Pagesangan, Pagesangan Barat, Pagesangan Timur, Mataram Timur, Punia dan Pejanggik.

\section{Deskripsi Statistik Tingkat Kapitalisasi}

Berdasarkan perhitungan nilai kapitalisasi (capitalization rate) menggunakan teori overall capitalization rate diketahui bahwa tingkat kapitalisasi di Kecamatan Mataram sangat bervariasi dengan nilai rata - rata sebesar 0,0439 (4,39\%), tingkat variasi nilainya terlihat pada gambar 2 berikut ini. 


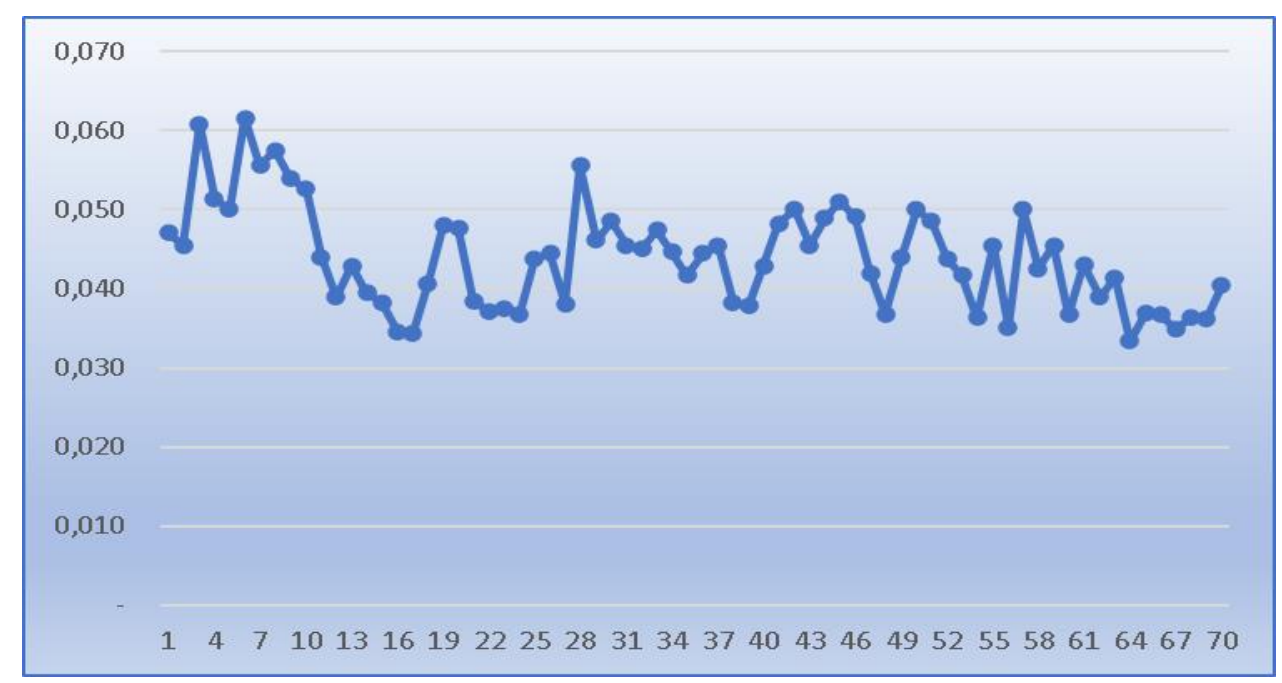

Gambar 2. Tingkat Kapitalisasi (Ro) Kecamatan Mataram

Adapun data untuk masing-masing kelurahan nilai tingkat kapitalisasinya juga bervariasi. Data tabel 2 berikut ini menunjukkan deskripsi statistik tingkat kapitalisasi pada setiap kelurahan.

Tabel 2. Pengukuran Tendensi Sentral dan Dispersi Tingkat Kapitalisasi

\begin{tabular}{|c|c|c|c|c|c|c|c|c|}
\hline No & Kelurahan & Mean & Median & Max & Min & Stdv & Var & $\mathbf{N}$ \\
\hline 1 & Pagutan Barat & $5,31 \%$ & $5,14 \%$ & $6,15 \%$ & $4,55 \%$ & $0,59 \%$ & $0,004 \%$ & 7 \\
\hline 2 & Pagutan & $4,59 \%$ & $4,34 \%$ & $5,75 \%$ & $3,82 \%$ & $0,71 \%$ & $0,006 \%$ & 8 \\
\hline 3 & Pagutan Timur & $4,01 \%$ & $3,85 \%$ & $4,80 \%$ & $3,44 \%$ & $0,53 \%$ & $0,003 \%$ & 7 \\
\hline 4 & Pagesangan & $4,39 \%$ & $4,42 \%$ & $5,56 \%$ & $3,68 \%$ & $0,60 \%$ & $0,004 \%$ & 8 \\
\hline 5 & Pagesangan Barat & $4,40 \%$ & $4,48 \%$ & $4,75 \%$ & $3,83 \%$ & $0,26 \%$ & $0,001 \%$ & 8 \\
\hline 6 & Pagesangan Timur & $4,67 \%$ & $4,86 \%$ & $5,11 \%$ & $3,78 \%$ & $0,41 \%$ & $0,002 \%$ & 8 \\
\hline 7 & Mataram Timur & $4,29 \%$ & $4,29 \%$ & $5,00 \%$ & $3,64 \%$ & $0,46 \%$ & $0,002 \%$ & 8 \\
\hline 8 & Punia & $4,22 \%$ & $4,28 \%$ & $5,00 \%$ & $3,52 \%$ & $0,46 \%$ & $0,002 \%$ & 8 \\
\hline 9 & Pejanggik & $3,70 \%$ & $3,65 \%$ & $4,14 \%$ & $3,33 \%$ & $0,25 \%$ & $0,001 \%$ & 8 \\
\hline & Kecamatan & $4,39 \%$ & $4,39 \%$ & $6,15 \%$ & $3,33 \%$ & $0,65 \%$ & $0,004 \%$ & 70 \\
\hline
\end{tabular}

Sumber : diolah dari hasil perhitungan statistik deskriptif

Pengukuran tendensi sentral dilakukan untuk mengetahui nilai rata-rata, nilai tengah, nilai maksimum dan nilai minimum. Pengkuran ini bertujuan untuk mengetahui indikasi awal terkait dengan karakteristik dan kecenderungan tingkat kapitalisasi sektor perumahan di daerah penelitian. Pada tabel 2 terlihat bahwa tingkat kapitalisasi rata-rata tertinggi terletak di Kelurahan Pagutan Barat sebesar 5,31\%, sedangkan tingkat kapitalisasi rata-rata yang terendah terletak di Kelurahan pejanggik yaitu sebesar 3,70\%. Hal ini berarti bahwa, dari sudut pandang investasi, Kelurahan 
Pagutan Barat adalah daerah yang paling tinggi tingkat pengembalian invesatasi rata-ratanya yaitu 5,31\%. Sedangkan kelurahan yang paling rendah tingkat pengembalian investasi rata-ratanya yaitu Kelurahan Pejanggik yaitu sebesar 3,70\%. Begitu juga untuk tingkat kapitalisasi individual, nilai tertinggi terletak di Kelurahan Pagutan Barat sebesar 6,15\% dan terendah di Kelurahan Pejanggik sebesar 3,33\%. Data menujukkan bahwa, baik secara rata-rata maupun secara individual, nilai kapitalisasi tertinggi terletak pada kelurahan yang sama yaitu kelurahan Pagutan Barat dan nilai kapitalisasi terendah terletak pada kelurahan Pejanggik.

Pengukuran dispersi dilakukan dengan menghitung standar deviasi dan varians tingkat kapitalisasi di semua kelurahan. Nilai standar deviasi secara keseluruhan yaitu sebesar 0,65\% dengan nilai tertinggi di Kelurahan Pagutan yaitu sebesar 0,71\% dan terendah ada di Kelurahan Pejanggik sebesar 0,25\%. Adapun nilai varians sangat kecil yaitu tertinggi sebesar 0,004\% dan terendah sebesar $0,001 \%$. Hal ini menujukkan bahwa sebaran data tingkat kapitalisasi di semua lokasi penelitian tidak memiliki perbedaan yang signifikan terhadap nilai rata-ratanya.

\section{Uji Regresivitas/Progresivitas Tingkat Kapitalisasi}

Pengujian ini dilakukan untuk mengetahui apakah properti perumahan yang mempunyai nilai pasar yang lebih rendah disewakan pada persentase yang lebih tinggi (regressive) atau sebaliknya, properti perumahan yang mempunyai harga pasar yang lebih tinggi disewakan pada persentase yang lebih tinggi (progressive). Untuk mengetahui ada tidaknya hubungan regresivitas atau progresivitas, dilakukan analisis regresi linier sederhana dengan metoda kuadrat terkecil (ordinary least square) dan analisis korelasi Spearman rank test.

\section{Analisis regresi}

Analisis regresi merupakan cara yang efektif untuk mendeteksi hubungan sistematis antara tingkat kapitalisasi (Ro) dan harga jual pasar (price) suatu properti. Berdasarkan hasil analisis regresi, diperoleh hasil sebagai berikut. Hasil analisis regeresi di bawah menujukkan bahwa nilai $\beta 1$ (price coefficient) tidak sama dengan nol $\left(\beta_{1} \neq 0\right)$ dan nilai $p$-value $<$ a $(0.0207<0.05)$ yang berarti bahwa Ho ditolak atau Ha diterima, dengan kata lain variabel X (price) menujukkan pengaruh yang signifikan terhadap variabel Y (tingkat kapitalisasi). Nilai koefisien negatif menujukkan setiap perubahan variabel harga $(\mathrm{X})$ berdampak pada penurunan variabel $\mathrm{Y}$ (tingkat kapitalisasi).

Hasil uji regresivitas/progresivitas diperoleh dari nilai konstanta ( $\beta 0)$ dan gradien ( $\beta 1)$, kemudian dibandingakan dengan nilai rata-rata tingkat kapitalisasi keseluruhan. Interpretasi hasil analisis regresi didasarkan pada kriteria berikut ini

1. Jika nilai koefisien $\beta 1=0$ dan koefisien $\beta o=$ tingkat kapitalisasi rata-rata ini berarti tidak ada hubungan antara tingkat kapitalisasi (Ro) dengan harga jual pasar (HJP). 
2. Jika nilai koefisien $\beta 1<0$ dan koefisien $\beta o>$ tingkat kapitalisasi rata-rata ini berarti terjadi hubungan yang cenderung regresif (regresivitas) antara tingkat kapitalisasi (Ro) dengan harga jual pasar (HJP).

3. Jika nilai koefisien $\beta 1>0$ dan koefisien $\beta o<$ tingkat kapitalisasi rata-rata ini berarti terjadi hubungan yang cenderung progresif (progresivitas) antara tingkat kapitalisasi (Ro) dengan harga jual pasar (HJP).

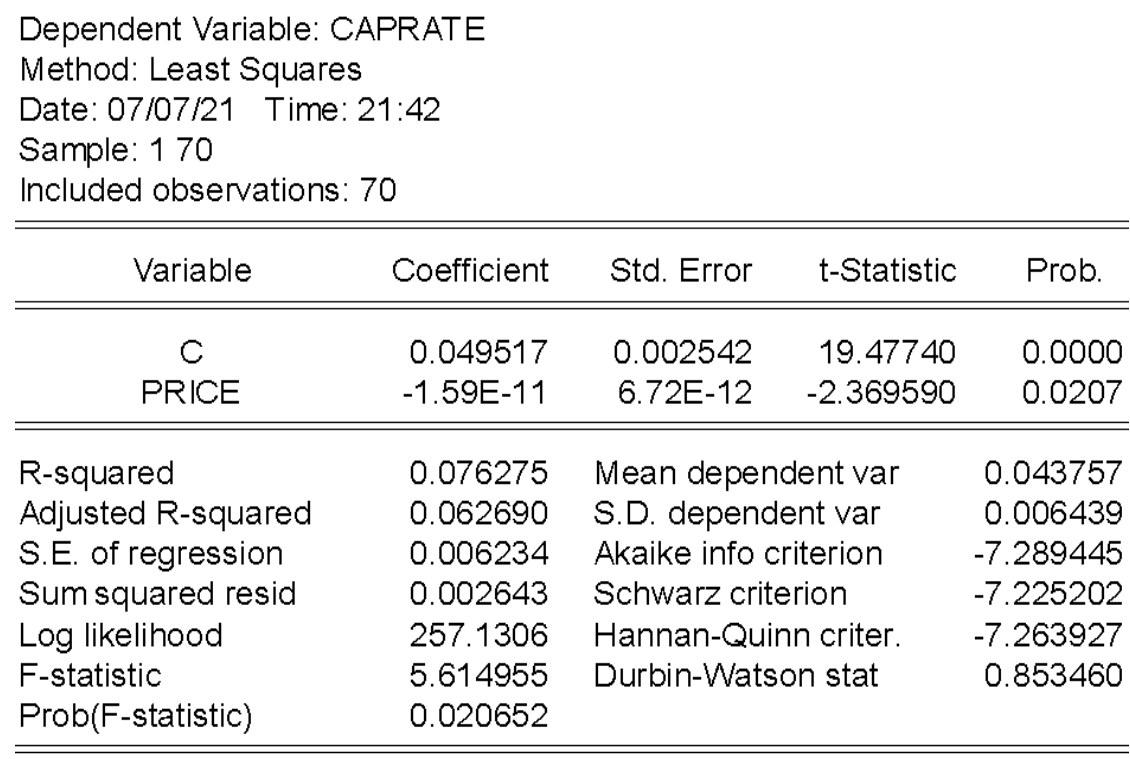

Interpretasi hubungan antara tingkat kapitalisasi (Ro) dengan harga jual pasar (HJP) diringkas pada tabel 3 berikut ini.

Tabel 3. Hasil Analisis Regresi Uji Regresivitas/Progresivitas

\begin{tabular}{|c|c|c|c|}
\hline $\begin{array}{c}\text { Constanta } \\
(\boldsymbol{\beta} \mathbf{)})\end{array}$ & $\begin{array}{c}\text { Price } \\
\text { Coefficient } \\
(\boldsymbol{\beta} \mathbf{1})\end{array}$ & $\begin{array}{c}\text { Average } \\
\text { Caprate }\end{array}$ & Interpretation \\
\hline 0.049517 & $-1.59 \mathrm{E}-11$ & 0.044 & Regressive \\
\hline
\end{tabular}

Sumber : diolah dari hasil analisis regresi.

Hasil analisis regresi menunjukkan bahwa nilai koefisien $\beta 1$ (price coefficient) sebesar -1.59E11 lebih kecil dari 0 dan nilai koefisien $\beta$ o sebesar 0.049517 lebih besar dari nilai rata - rata tingkat kapitalisasi keseluruhan sebesar 0.044. Hal ini berarti bahwa hubungan antara tingkat kapitalisasi (capitalization rate) dan harga pasar (market value) cenderung regresif atau terjadi regresivitas antara variabel harga dan variabel tingkat kapitalisasi. 


\section{Analisis korelasi Spearman.}

Selain melalui uji regresi, untuk memastikan ada tidaknya regresivitas/progresivitas maka dapat pula dilakukan analisis korelasi Spearman mengunakan bantuan program SPSS. Dengan kriteria pengujian yaitu, Jika nilai t-hitung $\geq$ t-tabel pada tingkat kepercayaan 95 persen dengan jumlah sampel 70 maka $\mathrm{H}_{\mathrm{o}}$ ditolak yang berarti bahwa terjadi re gresivitas antara variabel $\mathrm{Y}$ dengan variabel $\mathrm{X}$ atau dengan kata lain terdapat hubungan yang regresif antara tingkat kapitalisasi (Ro) dengan harga atau nilai pasarnya (market value).

Correlations

\begin{tabular}{|rll|r|r|}
\hline & & \multicolumn{1}{c|}{ Price } & \multicolumn{1}{c|}{ Caprate } \\
\hline Spearman's rho & Price & Correlation Coefficient & 1,000 &,$- 302^{\star \pi}$ \\
& & Sig. (1-tailed) & $\cdot$ &, 006 \\
& & $\mathrm{~N}$ & 70 & 70 \\
\cline { 2 - 5 } & Caprate & Correlation Coefficient &,$- 302^{\star \pi}$ & 1,000 \\
& & Sig. (1-tailed) &, 006 &. \\
& $\mathrm{~N}$ & 70 & 70 \\
\hline
\end{tabular}

**. Correlation is significant at the 0.01 level (1-tailed).

Hasil pengujian menunjukkan bahwa koefisien korelasi antara variabel harga dan tingkat kapitalisasi sebesar -0,302 ternyata lebih kecil dari t-tabel $=1,98$ (uji satu sisi, $\alpha=0,05$ ) sehingga hipotesis nol ditolak. Secara statistik dapat dikatakan bahwa terdapat hubungan yang regresif antara tingkat kapitalisasi (Ro) dan harga jual pasarnya (MV). Hubungan ini bermakna bahwa properti yang mempunyai harga pasar yang lebih tinggi ternyata disewakan pada tingkat persentase yang relatif rebih rendah dibandingkan dengan properti dengan harga pasar yang lebih rendah, begitu juga sebaliknya. Tanda negatif pada koefisien korelasi $(-0,302)$ menunjukkan arah hubungan antara variabel harga dan tingkat kapitalisasi yaitu semakin tinggi harga pasar suatu rumah maka tingkat kapitalisasinya cenderung semakin rendah, dan sebaliknya semakin rendah harga pasar suatu rumah ternyata memiliki tingkat kapitalisasi yang cenderung semakin tinggi.

\section{SIMPULAN}

Berdasarkan hasil analisis data dan pembahasan diperoleh beberapa kesimpulan sebagai berikut:

1. Untuk mendapatkan nilai pasar suatu properti (penilaian) dengan pendekatan pendapatan (income approach), khususnya pada metoda pengkapitalisasian langsung, tingkat kapitalisasi merupakan faktor yang harus ada. Metode kapitalisasi langsung mensyaratkan adanya nilai kapitalisasi khususnya pada properti yang memiliki aliran pendapatan (income producing property). 
Tingkat kapitalisasi akan berbeda ketika propertinya juga berbeda, bahkan perbedaan lokasi memungkinkan juga terjadinya perbedaan tingkat kapitalisasi meskipun dari jenis properti yang sejenis, hal ini terbukti setelah melakukan pengukuran tingkat kapitalisasi di Kecamatan Mataram. Dari hasil hasil penelitian diketahui bahwa tingkat kapitalisasi rata-rata sebesar 4,39\%. Yang menarik dari hasil penelitian ini adalah tingkat kapitalisasi rata- rata untuk masingmasing kelurahan sangat bervariasi antara 3,7\% sampai dengan 5,31\%. Tingkat kapitalisasi ratarata tertinggi terdapat di Kelurahan Pagutan Barat dan terendah di Kelurahan Pejanggik. Secara individual, tingkat kapitalisasi tertinggi yaitu sebesar 6,15\% yang terletak di kelurahan Pagutan Barat dan terendah di kelurahan Pejanggik. Tingkat kapitalisasi yang lebih tinggi berarti bahwa properti tersebut memiliki persentase imbal hasil yang lebih tinggi dibanding properti dengan tingkat kapitalisasi yang lebih rendah.

2. Berdasarkan hasil analisis regresi dan analisis korelasi menggunakan Spearman rank test diketahui bahwa tingkat kapitalisasi di lokasi penelitian cenderung regresif terhadap harga pasarnya atau terjadi regresivitas hubungan antara tingkat kapitalisasi dan harga pasarnya. Hal diartikan bahwa properti dengan harga pasar yang lebih tinggi mempunyai persentase imbal hasil yang lebih rendah daripada properti dengan harga pasar yang lebih rendah, dan begitu juga sebaliknya.

Jika ada peneliti selanjutnya yang tertarik untuk melakukan penelitian dengan tema yang sejenis, perlu kiranya untuk menambahkan jumlah sampel agar hasil penelitian yang diperoleh lebih baik dan lebih mewakili populasi. Berikutnya, perlu juga dilakukan identifikasi dan analisis terkait faktor-faktor atau varibel yang mempengaruhi tingkat kapitalisasi, karena setiap properti memiliki karakteristik yang berbeda dan berpengaruh pada nilai pasarnya. Selain itu juga, perlu dilakukan pengukuruan dan analisis tingkat kapitalisasi pada sektor properti selain perumahan seperti; kantor, gudang, ruko dan lain-lain, karena semakin banyak data tingkat kapitalisasi dari berbagai jenis properti akan semakin mudah untuk menentukan nilai pasar suatu properti.

\section{REFERENSI}

Accetta, G.J., 1998, “Supporting Capitalization Rates”, The Appraisal Journal, Oct 1998: 371-374. AIREA, 1987, The Appraisal of Real Estate, American Institute of Real Estate, Appraisal, Chicago. Anderson, D.R., Sweeney, D.J. dan Willims, T.A., 1996, Statistics for Business and Economics, Six edition, West Publishing Company, USA.

An, Xudong dan Deng,Yongheng, 2009, “A Stuctural Model for Capitalization Rate”, Real Estate Research Institut, February 2009: 1-24.

Appraisal Institute, 2001, The Appraisal of Real Estate, $12^{\text {th }}$ Edition, Appraisal Institute, Chicago. 
Safwira Guna Putra. Capitalization Rate on Residential Sector in Mataram

Argensio, J.D. dan Laurin, F., 2007, “The Real Estate Risk Premium: A Developed/Emerging Country Panel Data Analysis", Real EstateJournal, December 2007:1-41.

Direktorat Jenderal Pajak, 1994, "Undang-Undang Republik Indonesia No. 12 Tahun 1994 tentang Pajak Bumi dan Bangunan", Ditjen Pajak, Jakarta.

Gujarati, D.N., 2003, Basic Econometrics, $4^{\text {th }}$ Edition, McGraw-Hill, Singapore Gujarati, D.N. dan Porter, D.C., 2009, Basic Econometrics, $5^{\text {th }}$ Edition, McGraw-Hill, Singapore.

IAAO, 1996, Property Assessment Appraisal, International Association of Assessment Officer, Chicago, Illionis.

Lusht, K.M., 1997, Real Estate Valuation, Principles and Application, USA.

Mooney, S.P., Vergin, T.L. dan Mortrude, S.J., 1998, "Why CapitalizationRates Of SingleTenant Property Vary", The Appraisal Journal, Oct 1998: 366-379.

Simons, R., Arbel, Y., Choi, E. dan Shahrar, D.B., 2011, "Explaining theVariation in Residential Capitalization Rates Worldwide: A PreliminaryInvestigation", The ERES Journal, June 2011: $1-10$.

Sivitanides, P.S., Southard, J., Torto, R.G. dan Wheaton, W.C., 2001, “The Determinants of Appraisal-Based Capitalization Rates", Real Estate Finance Journal, March 2001: 1-27.

Sivitanidou, R.C. dan Sivitanides, P.S., 1997, “Exploring Capitalization Rates Differentials Across Property Types”, Real Estate Journal, March 1997: 1-11.

Kantor Perwakilan NTB, Bank Indonesia, 2021, Laporan Perekonomian Provinsi Nusa Tenggara Barat, Februari 2020. 